\title{
SOE Reform in China: Past, Present and Future
}

\author{
XIN LI AND KJELD ERIK BRØDSGAARD
}

\begin{abstract}
This article analyses the evolution of SOE reform in China, especially focusing on how SOEs benefited from the Chinese government's favourable policies and how such SOE favouritism impacts the Chinese macro economy and causes social problems. The article outlines SOE reform before Hu Jintao and Wen Jiabao took over the leadership of the country in 2002-2003 and investigates the nominal as well as the real performance of SOEs since 2003. The article also discusses the nature and functions of Chinese SOEs as well as the future direction of Chinese SOE reform.
\end{abstract}

Keywords: China, SOE, reform, favouritism, privately owned enterprises

\section{Introduction}

In 1979, China adopted the reform and opening policy and started its transition from a centrally planned economy to a market economy. One important component of the reform programme was the reform of state-owned enterprises (SOEs). Initially, the idea was to revitalize the inefficient SOE sector by expanding the SOEs' autonomy in operational decisions. But the reform was not successful. Later on, the goal of the reform was changed, to privatize some of the loss-making SOEs and to allow the private economy to prosper.

After three decades of market-oriented economic reform, more than 40 per cent of China's non-agricultural GDP is still accounted for by the visible state sector - SOEs and entities directly controlled by SOEs (Szamosszegi and Kyle 2011). Furthermore, Chinese SOEs dominate strategic sectors such as the oil, power and telecommunication industries, the so-called 'commanding heights' of the economy. Since 2003, the overall financial performance of Chinese SOEs has looked outstanding in terms of growth of assets and profits. However, SOEs have been the target of serious criticism from intellectuals and the public in China.

To understand this paradoxical situation, this article analyses SOE reform in China, especially focusing on how the SOEs benefited from 
the Chinese government's favourable policies and how such favouritism impacts the Chinese macro economy and causes social problems. In the final section, we discuss the future direction of Chinese SOE reform.

\section{The Past: China's SOE Reform before 2003}

After Mao's death in 1976, when Deng Xiaoping became the de facto supreme leader of the Chinese Communist Party (CCP), his major goal was to lay the foundation for rapid and sustained economic growth. Supported by other reform-oriented CCP leaders, Deng Xiaoping in 1979 launched the economic reform and open door policies. However, in accordance with his pragmatic and strategic approach, Deng postponed the urban sector reform, including the SOE reform, until 1984 when the huge success of the rural sector reform provided sufficient confidence and a solid economic foundation to push reforms to a higher level.

\section{The Efficiency Problem of Chinese SOEs}

The biggest problem that China's SOEs faced in the early 1980s was low efficiency. Under the central planning system, there was no competition because the whole economy was publicly owned and state-run; therefore the low efficiencies of Chinese SOEs could hardly be revealed. After the reform and opening up began, it soon became clear that Chinese SOEs had difficulties adjusting to the changing reality, including increased competition from collectively owned enterprises (COEs), privately owned enterprises (POEs), and foreign-invested enterprises (FIEs). In general, low efficiency seems to be endemic to any centrally planned economy. In the case of Chinese SOEs, two major factors contributed to the inefficiency problem: the lack of incentives in the SOE workforce and the heavy social burdens the SOEs shouldered.

Why did the Chinese SOE workforce lack incentives? The reason was that under China's central planning system, SOEs were actually 'workshops' of the big 'national factory', passively performing the production tasks ordered by the central planners. All profits had to be handed in to the central government and there were no performance measures. Workers enjoyed job security, so there was no incentive for workers to work harder to improve efficiency. In the first phase of reform, although SOEs were in competition with COEs, POEs and FIEs, the SOEs received favourable treatment from the government and enjoyed soft budget constraints; so, there was still no real incentive for workers to improve efficiency because they knew the SOEs would be bailed out if the SOE made losses. 
There were two types of social burdens on Chinese SOEs. One was that Chinese SOEs were in general overstaffed to provide as much employment as possible. The other was that Chinese SOEs undertook many social functions such as running schools, hospitals, cinemas, canteens and even convenience stores. One reason for taking on these social functions was that this maintained social stability, as SOE workers would have almost all their social needs met within their danwei (i.e., working unit). In addition, some SOEs located in remote or isolated 'third line' regions had to provide those social functions for their employees simply because there were no alternatives.

\section{The Two Phases of the Reform before 2003}

The reform before 2003 can be roughly divided into two phases. The first phase was from 1979 to 1992 under the leadership of Deng Xiaoping. During the first phase the emphasis of the reform was on enterprization, that is, transforming the SOEs from the government's affiliated organizations under the centrally planned economy into autonomous, productive enterprises under the planned commodity economy. ${ }^{1}$ The culmination of this reform was the promulgation of the 'Law of Industrial Enterprises Owned by the Whole People' in $1988 .^{2}$ The key to such a transformation was thought to be incentivizing SOE managers and employees. To do so, the Chinese government undertook two experiments. One was to adopt the policy of 'fang quan rang $l i$ ' from 1979 to 1986, which aimed to delegate more power to and leave more profits for the enterprises. The other was to implement the 'contract management responsibility system' from 1987 to 1992. These two experiments were effective in boosting the SOEs' production output but not effective in increasing the government's fiscal revenue. This was due to the problems of information asymmetry and moral hazard rooted in the principal-agent relationship between the government and the SOEs. With the fang quan rang li policy, SOE managers, once having gained more power and autonomy, were motivated to grab as much as possible of the profit that they were required to hand over to the state. Under the contract system, SOE managers could bargain with the state for conditions in their favour (Lin and Li 2003).

The second phase was from 1992 to 2002 under Jiang Zemin's leadership. In 1992, following Deng's 'Southern Tour', the Chinese government started a new round of SOE reform, which aimed to address the property rights issue. The reform theme of this phase can be termed corporatization because the overall economic reform was redirected 
towards establishing a socialist market economy, and the new goal of the SOE reform was to transform the SOEs into modern corporations characterized by clearly defined property rights, clear-cut responsibility and authority, and separation of the functions of government and enterprises. A major solution was to transform SOEs into stockholding companies. To facilitate this transformation, the Chinese government issued the Company Law in 1993. However, once the marketization reform started, Chinese SOEs appeared to be ineffective and inefficient compared with COEs, POEs and FIEs. By the mid-1990s, more than 60 per cent of the 11,000 largest SOEs were loss-making (SASAC 2008). In 1997, the Chinese government gave up the idea of bailing out every loss-making SOE and adopted a 'zhua da fang xiao' strategy, namely, grasping the big SOEs while letting go of the small ones. The same year, the Chinese government implemented a programme to pull the big SOEs out of difficulties within three years (san nian tuo kun, from 1998 to 2000). By the end of 2000, this programme was said to have basically succeeded (SASAC 2008), although the Chinese government and people have paid a huge cost, including writing off 1.4 trillion yuan in non-performing loans of state-owned banks.

\section{The Present: SOE Reform under the $\mathrm{Hu}-\mathrm{Wen}$ Administration since 2003}

After $\mathrm{Hu}$ Jintao and Wen Jiabao assumed the leadership roles in 2003, the reform of Chinese SOEs entered into its third phase with the establishment of the State-owned Assets Supervision and Administration Commission (SASAC) of the State Council. The reform theme of this phase can be termed concentration. Under the management of the SASAC, Chinese SOEs were concentrated in several strategically important industries while exiting from areas where SOEs lacked competitiveness. Now, state-owned enterprises have absolute control in seven industries: defence, electricity generation and distribution, petroleum and petrochemicals, telecommunications, coal, civil aviation and waterway transport (World Bank 2012: 105). It is worth noting that there is a commercial orientation to this phase of SOE reform, in the sense that the big SOEs which the Chinese government 'grasps', are now expected to act as ordinary enterprises and to seek profits. This commercial orientation is a natural consequence of the function and purpose of the SASAC, ${ }^{3}$ which is charged with the sole responsibility of supervising the preservation and expansion of the value of the state-owned assets of the 114 central 
enterprises (zhongyang qiye). ${ }^{4}$ Li Rongrong, the first Chairman of the powerful SASAC, has repeatedly said that China should develop the state-owned economy 'unwaveringly' and 'righteously' (Li 2009).

\section{The Nominal Performance of SOEs since 2003}

Entering the new century, Chinese SOEs have morphed from the government's loss-making burden into its profit-making favourite. According to the 'SASAC Review 2009' (see Table 1), from 2003 to 2009, the total number of SOEs decreased from 149,988 to 115,115; however, total SOE assets expanded from 19,710.3 billion yuan to 53,537.2 billion yuan, accounting for 18.1 per cent average annual growth; the total revenue of SOEs increased from 10,734 billion yuan to $24,200.8$ billion yuan, registering a 14.5 per cent annual growth; and the total profits grew from 495.1 billion yuan to 1,570.3 billion yuan, for a 21.2 per cent annual growth. As a result of this performance improvement, the tax contribution of the SOEs grew from 810.5 billion yuan in 2003 to 2,279.6 billion yuan in 2009 , with an average annual growth of 18.8 per cent.

TABLE 1: Major Financial Indicators of Chinese SOEs, 2003-2009 (billion yuan)

\begin{tabular}{|c|c|c|c|c|c|c|c|c|c|}
\hline Year & $\begin{array}{c}\text { Number } \\
\text { of SOEs }\end{array}$ & $\begin{array}{c}\text { Total } \\
\text { assets }\end{array}$ & $\begin{array}{c}\text { Growth } \\
\text { (in \%) }\end{array}$ & $\begin{array}{c}\text { Total } \\
\text { rev- } \\
\text { enues }\end{array}$ & $\begin{array}{c}\text { Growth } \\
\text { (in \%) }\end{array}$ & $\begin{array}{c}\text { Total } \\
\text { profits }\end{array}$ & $\begin{array}{c}\text { Growth } \\
\text { in \%) }\end{array}$ & $\begin{array}{c}\text { Total } \\
\text { tax paid }\end{array}$ & $\begin{array}{c}\text { Growth } \\
\text { (in \%) }\end{array}$ \\
\hline 2003 & 149,988 & $19,710.3$ & & $10,734.0$ & & 495.1 & & 810.5 & \\
\hline 2004 & 137,753 & $22,308.4$ & 13.2 & $12,325.4$ & 14.8 & 752.5 & 52.0 & $1,010.7$ & 24.7 \\
\hline 2005 & 127,067 & $25,372.2$ & 13.7 & $14,249.0$ & 15.6 & 968.3 & 28.7 & $1,191.9$ & 17.9 \\
\hline 2006 & 119,254 & $29,011.6$ & 14.3 & $16,196.9$ & 13.7 & $1,224.2$ & 26.4 & $1,393.7$ & 16.9 \\
\hline 2007 & 115,087 & $35,481.4$ & 22.3 & $20,082.3$ & 24.0 & $1,762.5$ & 44.0 & $1,768.9$ & 26.9 \\
\hline 2008 & 113,731 & $42,547.3$ & 19.9 & $22,936.4$ & 14.2 & $1,330.7$ & -24.5 & $2,092.8$ & 18.3 \\
\hline 2009 & 115,115 & $53,537.2$ & 25.8 & $24,200.8$ & 5.5 & $1,570.3$ & 18.0 & $2,279.6$ & 8.9 \\
\hline
\end{tabular}

Source: SASAC (2010).

With regard to the central SOEs, i.e., the largest SOEs directly supervised by the SASAC of the State Council, their performances appear to be excellent (see Table 2). From 2002 to 2009, total assets of the central SOEs ballooned from 7.1 trillion yuan to 21 trillion, with an average annual growth of 16.7 per cent; operating revenues rose from 3.4 trillion yuan to 12.6 trillion, growing 20.8 per cent annually; profits increased from 240.5 billion yuan to 815.1 billion yuan, with 19 per cent annual growth; and total tax paid to the state mushroomed from 291.5 billion yuan to 1.2 trillion, accounting for a 21.6 per cent annual growth (SASAC 2010). Over this period, the number of SOEs whose operating revenue 
exceed 100 billion yuan increased from 6 to 38, while the number of Chinese SOEs listed in the Fortune 500 rose from 6 to 30. Further gains were achieved in the 2009-2012 period. At the end of 2012, total assets of central SOEs had soared to 44.8 trillion yuan. Total operating revenues amounted to 22.5 trillion yuan, with profits of 1.3 billion yuan.

TABLE 2: Major Financial Indicators of China's Central SOEs, 2002-2012 (billion yuan)

\begin{tabular}{|l|r|r|r|r|c|c|}
\hline Year & $\begin{array}{l}\text { Total } \\
\text { assets }\end{array}$ & $\begin{array}{l}\text { Total } \\
\text { operating } \\
\text { revenues }\end{array}$ & $\begin{array}{l}\text { Total } \\
\text { profits }\end{array}$ & $\begin{array}{l}\text { Total } \\
\text { tax paid }\end{array}$ & $\begin{array}{l}\text { Number of SOEs } \\
\text { making more } \\
\text { than 100 billion } \\
\text { yuan in revenue }\end{array}$ & $\begin{array}{l}\text { Number of } \\
\text { SOEs listed } \\
\text { in Fortune } \\
500\end{array}$ \\
\hline 2002 & $7,128.5$ & $3,364.3$ & 240.6 & 291.5 & 6 & 6 \\
\hline 2003 & $8,323.2$ & $4,474.8$ & 300.6 & 356.3 & 9 & 8 \\
\hline 2004 & $9,149.4$ & $5,599.7$ & 488.0 & 465.5 & 10 & 10 \\
\hline 2005 & $10,514.8$ & $6,794.5$ & 637.7 & 578.0 & 15 & 13 \\
\hline 2006 & $12,191.5$ & $8,294.0$ & 768.2 & 682.3 & 21 & 16 \\
\hline 2007 & $14,923.1$ & $10,028.2$ & $1,005.6$ & 879.2 & 26 & 19 \\
\hline 2008 & $17,628.8$ & $11,870.5$ & 696.2 & $1,042.6$ & 33 & 24 \\
\hline 2009 & $21,058.1$ & $12,627.2$ & 815.1 & $1,147.5$ & 38 & 30 \\
\hline 2010 & $24,300.0$ & $16,700.0$ & $1,131.5$ & $1,400.0$ & 43 & 38 \\
\hline 2011 & $28,000.0$ & $20,200.0$ & 917.3 & $1,700.0$ & & 59 \\
\hline 2012 & $44,790.0$ & $22,500.0$ & $1,300.0$ & $1,900.0$ & & 65 \\
\hline
\end{tabular}

Sources: SASAC (2010); 2010 figures are from SASAC websites, available at http://www. sasac.gov.cn/n1180/n1566/n259730/n6633400/13353073.html and http://www.sasac.gov. cn/n1180/n1566/n259730/n6633400/13225460.html; 2011 figures are from Caijing, available at: http:/ / economy.caijing.com.cn/2012-02-21/111697734.html; the 2012 total assets figure is from Global Times, available at: http:/ / finance.huanqiu.com/comment/2013-05/3908080.html; the other 2012 financial figures are from Xinhua News Agency, available at: http://news.xinhuanet. com/fortune/2013-03/12/c_124445850.htm.

With this achievement, Li Rongrong, the 'Big Boss' of China's large SOEs, said he felt satisfied and pleased in his retirement speech on 24 August 2010 (Li 2010a). He revealed that the then premier, Wen Jiabao, was very happy about the work of SASAC because Wen only asked for the preservation of the state-owned assets, while the SASAC managed to expand them rapidly. ${ }^{5}$ Given this, Li expected the Chinese people to appreciate his contributions. However, he was surprised by all the criticism directed towards the SOEs and the SASAC, which ranged from administrative monopoly to paying little in dividends to the state and to corruption in SOEs. ${ }^{6}$ Li once lamented that 'when the SOEs were managed badly, we were blamed; now they are managed well, but we are still blamed. I don't understand why'. ${ }^{7}$ To resolve Li's puzzle, one has to go beyond the nominal performance of the SOEs and probe into the sources 
of their huge profits to understand the real performance of the SOEs. One plausible reason for the puzzle is that there is a huge difference between the nominal and the real performance of the SOEs; while Li only knows or only talks about the former, the public is concerned about the latter.

\section{The Real Performance of the SOEs}

Many people inside and outside China are interested in understanding how the Chinese state-owned sector has been transformed from the government's financial burden in the 1990s into its 'cash cow' in the 2000s. However, where the ever-growing profits of the SOEs come from remains an obscure question. Ordinary Chinese people can hardly figure it out but have to accept the official explanation due to the media control in China. However, a recent report by the Unirule Institute of Economics (2011), a Beijing-based independent think tank, has provided an alternative viewpoint that uncovers an untold truth about the super profitability of the Chinese SOEs.

According to this report, four major factors have contributed to huge SOE profits, including (1) unpaid rents for nationally owned lands that were given to the SOEs for free or at very low prices; (2) unpaid rents

TABLE 3: Benefits Accrued to the SOEs due to Government Favouritism, 2001-2009 (million yuan)

\begin{tabular}{|l|c|c|c|c|c|c|c|c|c|}
\hline & 2001 & 2002 & 2003 & 2004 & 2005 & 2006 & 2007 & 2008 & 2009 \\
\hline $\begin{array}{l}\text { Unpaid } \\
\text { land rents }\end{array}$ & 376,900 & 385,600 & 397,000 & 408,900 & 401,900 & 423,200 & 492,700 & 516,800 & 528,200 \\
\hline $\begin{array}{l}\text { Unpaid } \\
\text { resource } \\
\text { rents-oil }\end{array}$ & 16,519 & 16,143 & 18,896 & 24,994 & 40,969 & 30,538 & 28,897 & 25,084 & 41,633 \\
\hline $\begin{array}{l}\text { Unpaid } \\
\text { resource } \\
\text { rents-nat- } \\
\text { ural gas }\end{array}$ & 873 & 974 & 1,073 & 1,321 & 1,755 & 2,061 & 2,503 & 3,334 & 3,676 \\
\hline $\begin{array}{l}\text { Unpaid } \\
\text { resource } \\
\text { rents-coal }\end{array}$ & 11,527 & 13,795 & 15,062 & 18,393 & 25,483 & 28,595 & 34,974 & 42,354 & 46,201 \\
\hline $\begin{array}{l}\text { Lower } \\
\text { bank inter- } \\
\text { est rates }\end{array}$ & 217,983 & 220,101 & 208,670 & 309,186 & 235,078 & 275,565 & 350,914 & 482,184 & 454,169 \\
\hline $\begin{array}{l}\text { Fiscal } \\
\text { subsidies }\end{array}$ & 26,176 & 21,401 & 19,404 & 18,198 & 16,657 & 18,022 & 17,757 & 95,551 & 80,957 \\
\hline Total & 649,978 & 658,014 & 660,105 & 780,992 & 721,842 & 777,981 & 927,745 & $1,165,307$ & $1,154,836$ \\
\hline
\end{tabular}

Source: Unirule Institute of Economics (2011). 
for nationally owned natural resources such as oil, natural gas and coal, which were extracted by resource-based SOEs at very low prices; (3) cheap loans and credits from state-owned banks; and (4) the government's fiscal subsidies. From Table 3 we can see that from 2001 to 2009, on average SOEs paid 833 billion yuan less than what they should have paid annually. In total, for the nine years from 2001 to 2009, 7,496.8 billion yuan was not paid and instead was appropriated by the SOEs as part of their nominal profits. This figure does not include the unpaid rents for other natural resources such as ferrous and nonferrous metals as well as license fees for telecommunication resources such as $3 \mathrm{G}$ networks.

If those benefits derived from policies favouring the SOES were deducted from the nominal profits, one can see that the real profits of Chinese SOEs were in fact negative in all years except two from 2001 to 2009 (see Table 4). In other words, while the SOEs are making profits for the Chinese government, they are making losses for their ultimate owners, i.e., the Chinese people.

TABLE 4: Nominal and Real Profits of Chinese State-owned and Stateholding Enterprises (million yuan)

\begin{tabular}{|l|c|c|c|c|c|c|c|c|c|}
\hline & 2001 & 2002 & 2003 & 2004 & 2005 & 2006 & 2007 & 2008 & 2009 \\
\hline $\begin{array}{l}\text { Nomi- } \\
\text { nal } \\
\text { profits }\end{array}$ & 238,856 & 263,294 & 383,620 & 545,310 & 651,975 & 848,546 & 1079,519 & 906,359 & 928,703 \\
\hline $\begin{array}{l}\text { Real } \\
\text { profits }\end{array}$ & $-411,122$ & $-394,720$ & $-276,485$ & $-235,682$ & $-69,867$ & 82,377 & 161,907 & $-139,090$ & $-362,544$ \\
\hline
\end{tabular}

Source: Unirule Institute of Economics (2011).

Before the publication of this report, voices were raised in the media and on the internet that doubted and even challenged the official discourse. Especially worth mentioning is the widely publicized debate on whether there has been a trend in the Chinese economy whereby 'the state sector is advancing while the private sector is retreating' (guo jin, $\min \mathrm{tui}$ ). On one side of the debate some liberal intellectuals have argued that there indeed are some areas in which the state sector advances while the private sector retreats. On the other side are government officials and pro-CCP scholars who have argued that no such trend exists. It seems that within academic circles, more people sympathize with the opinions of the liberal intellectuals. Nevertheless, the Chinese government has been resisting criticism and is protecting the SOEs. A question remains: why is this so? To answer this question, we need to understand the Chinese government's view on the nature, purpose, function and boundary of SOEs. 


\section{The Nature, Purpose, Function and Boundary of SOEs}

\section{A Normative View}

By nature, a state-owned enterprise is fundamentally different from a privately owned enterprise. The two differ in four aspects: source of initial funds, formation of the firm, strategic decision making and ultimate risk bearing (see Table 5). First, unlike POEs, the initial funds for establishing an SOE are from the state's coffers. Since the money comes from tax revenues, the taxpayers or all citizens of a nation are the ultimate owners of the SOEs, while the state is just the agent of the citizens. Second, with regard to formation of a firm, shareholders voluntarily form a POE; but in the case of an SOE, it is the state's will, or more precisely, it is the will of some small group of politicians who decide on its formation, regardless of the wishes of the real shareholders (i.e., the taxpayers). Third, in terms of strategic decision making in the firm, in the case of a POE, the shareholders can participate in person or via the board of directors they have selected, while in the case of an SOE, it is normally the state that makes the decisions unilaterally without consultation with the taxpayers. Finally, when it comes to ultimate risk bearing, in the case of a POE, the individual shareholders bear limited liability in proportion to their shares; but in the case of an $\mathrm{SOE}$, the state often uses tax money to bail out a bankrupt SOE, which means that the taxpayers bear unlimited liability for wrongdoings that they have nothing to do with.

The nature of SOEs dictates the purpose of SOEs, which is to better serve the people, the real owners of the SOEs, by correcting for market deficiencies (Chang 2007: 6). The reason is straightforward: a government is in principle the agent of the people it governs. This is accepted in the West as well as in China where the CCP claims it serves the Chinese people and has no independent interests. So, when a government establishes SOEs by using tax money collected from its people, it must use the SOEs to serve its people rather than any other purpose, such as making profits.

The nature, purpose, and function of SOEs then determine the boundary of SOEs, namely, SOEs should only undertake those commercial activities that the private sector (i.e., individual citizens and private enterprises) is unwilling, incapable, or too inefficient to undertake, and where national security is involved or people's livelihoods may be adversely affected by the potential opportunistic conduct of the private 
TABLE 5: Differences between State-owned and Privately-owned Enterprises

\begin{tabular}{|l|l|l|}
\hline & $\begin{array}{l}\text { Privately owned enterprises } \\
\text { (POEs) }\end{array}$ & $\begin{array}{l}\text { State-owned enterprises } \\
\text { (SOEs) }\end{array}$ \\
\hline Source of initial funds & Individuals' private money & $\begin{array}{l}\text { State fiscal revenue, but } \\
\text { ultimately taxpayer money }\end{array}$ \\
\hline Formation of the firm & $\begin{array}{l}\text { Shareholders' voluntary } \\
\text { behaviour }\end{array}$ & $\begin{array}{l}\text { State's will, regardless of } \\
\text { the real shareholders (tax- } \\
\text { payers) wishes }\end{array}$ \\
\hline Strategic decision making & $\begin{array}{l}\text { Shareholders participate } \\
\text { in person or via board of } \\
\text { directors }\end{array}$ & $\begin{array}{l}\text { State unilaterally makes } \\
\text { decisions, taxpayers not } \\
\text { involved }\end{array}$ \\
\hline Ultimate risk bearing & $\begin{array}{l}\text { Individual shareholders } \\
\text { bear limited liabilities }\end{array}$ & $\begin{array}{l}\text { State can use tax money } \\
\text { to bail out SOE, taxpayers } \\
\text { bear the risks }\end{array}$ \\
\hline
\end{tabular}

sector. According to the principle of subsidiarity, a higher level of collective organization should not intervene in what a lower level can do. Therefore, the SOEs should not enter into commercial areas where the private sector can do better and SOEs, whatever their reason for existence, should gradually exit from commercial activities that the private sector is capable of undertaking (Chen 2012). Accordingly, SOEs should only exist to provide public goods (which POEs are unwilling to do), to undertake large infrastructure projects like national rail networks (which POEs are incapable of doing), to run public utilities such as water supply and power transmission (as natural monopolies), to run military and nuclear industries (in which national security is involved) and to be a reactive player as a national grain reserve operator (as people's livelihood may be adversely affected by private grain firms' opportunistic behaviour).

\section{The Chinese Government's View}

During Mao's time, under central planning, the SOEs were actually affiliated organizations of the government, playing the role of workshops of the big national 'factory' as well as working units (danwei) providing social welfare to Chinese workers. In the heyday of the Chinese Communist movement, public ownership (i.e. SOEs and collectively owned enterprises) was seen as the only legitimate form of economic organization, and the nature of SOEs was taken for granted and needed no discussion. After the reform began, this taken-for-grantedness seems to have been inherited to a large extent. This is to say, the Chinese government did not have a clear understanding of the nature of the SOEs. The CCP, at its Fourth Plenum of the 15th Central Committee held on 
22 September 1999, defined the function of state ownership and listed four areas to be controlled by state firms: national security, natural monopolies, public goods, and pillar and high-tech industries (Central Committee of the Communist Party of China 1999).

Later, the Chinese government redefined the functions of SOEs, reflected in the speech of Xi Jinping, China's then vice president, at the Conference on Party Building Works of SOEs, held on 17 August 2009 (Xi 2009). In his speech, Xi commented on the role of SOEs as 'the important force of building a well-off society, the important pillar of Socialism with Chinese Characteristics, and the important basis of CCP's ruling'. In accordance with Xi's comment, one can identify four major functions with decreasing importance that the Chinese government has assigned to the SOEs.

The first one is to justify the claim that China is a socialist country by the very existence of SOEs. With the economic reform and opening up, over three decades China has been rapidly transformed from one of the most egalitarian to one of the most unequal societies in the world. After the Chinese government dismantled and marketized the social welfare system attached to the SOEs, the only defensive argument the Chinese government has in the face of such accusations is that there is still a strong and important state-owned economy.

The second function of SOEs is to provide the financial basis for the CCP's ruling. To rule the country, the Party needs ideological, material and military support. It is generally believed that the communist ideology has been losing appeal in China. If military support is the bottom line for the CCP's ruling in a time when mass incidents frequently take place, then the Party must control enough financial resources to have a strong and loyal military force. People might wonder why the CCP, the only ruling party, needs the SOEs as a source of financial support as they can have income by taxation. There are at least two reasons. First, in principle, tax revenue is subject to fiscal budget planning and monitoring. Second, in a one-party-ruled country, the ruling party can easily transform state-owned assets into Party-owned assets. An example of this is the Chinese Nationalist Party (the KMT), which claimed massive so-called KMT-owned assets that in fact were state-owned after the democratization in Taiwan.

The third function of SOEs is to be an executor of the Chinese government's industrialization strategy. Since the foundation of the People's Republic of China, the Chinese government has adopted a state-led, investment-driven industrialization strategy. The SOEs seem to have 
been given major responsibilities to implement such a strategy. Even if the SOE sector has dramatically shrunk in terms of its share in the Chinese national economy, the function of implementing the government's industrialization strategy has never been undermined. Especially with the advent of the global big business revolution since the 1980s (Nolan 2002), which brings huge challenges to the developing countries, the Chinese government has adopted a strategy of creating a 'national team' of big SOEs that can participate in international competition for resources and markets.

The fourth function is to serve in the interest of national security and the people's livelihood (guo ji min sheng). Although national security and people's livelihood should be the most important justification for the existence and development of SOEs, it seems that the people's livelihood is the least important function on the Chinese government's agenda. This does not imply that the CCP does not care about the people's livelihood, but it has placed more importance on the other three functions of the SOEs.

Due to the designated functions of SOEs, the proper boundary/scope of SOEs in the eyes of the Chinese government becomes obvious. First, no matter how well the private economy is developing and how much further the state-owned economy as a percentage of the GDP is reduced, there must be some SOEs to represent the publicly owned economy to justify the claim that China is socialist but with Chinese characteristics. In the words of Li Rongrong, 'no matter how the SOE reform proceeds, the leading role of state-owned economy in the national economy will never change' (Li 2003). This may explain why the SASAC strongly opposed the World Bank's report China 2030, which suggested downsizing the Chinese state sector by a new round of SOE restructuring (Caijing 2012). Second, for SOEs to be an important source of financial support for the $\mathrm{CCP}$ 's rule, they must be profit-making rather than loss-making. Guided by the policy of 'grasping the large and letting go of the small', the small loss-making SOEs are privatized; the medium-sized SOEs are bailed out; and the large SOEs are firmly controlled and made profitable at whatever cost, including granting them monopoly status and giving fiscal subsidies. Third, to implement the government's investment-driven industrialization strategies, SOEs now dominate those industries that need large-scale investment, such as oil and petrochemicals, railways and aerospace. Finally, SOEs firmly control the military and nuclear industries for national security reasons, and SOEs also compete in the grain market, which is linked to the Chinese people's livelihood. 
From the above analysis, it seems that the Chinese government will do whatever it can to protect and strengthen the SOEs. However, there are other factors the $\mathrm{CCP}$ has to take into consideration that may constrain its policy making and pave the way for further SOE reform in the future. One particularly relevant factor is the negative impact of SOE favouritism on the Chinese macro economy.

\section{Negative Impacts of SOE Favouritism on China's Macro Economy}

\section{The Impact on the Private Sector}

Enjoying all sorts of governmental support, Chinese SOEs have been competing with privately owned enterprises on an unequal footing. Accompanying the rising profits of the SOEs is the deterioration of the operating environment of private enterprises. This deterioration is due to two major reasons: one is the difficulty of access to bank finance that is largely channelled to SOEs, the other is the restriction of entry into profitable industries controlled by SOEs.

In China, the state-owned banks play a dominant role in the financial market and they favour SOEs in allocating loans and credits because, as mentioned above, Chinese SOEs are assigned the function of implementing the state's investment-driven industrialization strategy. In China, loans and credits given to SOEs account for a very large share of total bank loans and credits. According to the Report on the Development of Private Economy in China 2008-2009, ${ }^{8}$ from 2002 to 2008, the narrow private sector (i.e., domestic privately owned and individual businesses) only accounted for 13.5 per cent of the total bank loans issued (see Table 6). Many finance-hungry small and medium-sized, private enterprises often have to resort to private and even underground financial markets. According to one study (Li 2008, cited in Lardy 2008), by the end of June 2008 , underground lending stood at 10 trillion yuan, equivalent to almost a third of the loans extended through the banking system. However, the costs of using underground financing are very high. Some people estimate the average black market lending rate may be as high as 25 per cent per year compared to the official lending rate of 6.0 per cent set by China's central bank in 2012. ${ }^{9}$

Since the 1990s, the Chinese central government has been deregulating many industries, such as real estate, banking, automotive and coal mining, which were once tightly controlled and monopolized by the 
TABLE 6: Loans Given to the Private Sector in China, 2002-2008 (in per cent)

\begin{tabular}{|l|c|c|c|c|c|c|c|}
\hline & 2002 & 2003 & 2004 & 2005 & 2006 & 2007 & 2008 \\
\hline Broad private sector & 54.1 & 58.1 & 58.8 & 61.3 & 61.1 & 59.2 & 61.1 \\
\hline Domestic private sector & 47.3 & 51.8 & 52.5 & 54.6 & 54.3 & 49.8 & 53.0 \\
\hline Narrow private sector & 7.4 & 8.9 & 7.7 & 8.2 & 8.9 & 13.5 & 13.0 \\
\hline
\end{tabular}

Note: The broad private sector is defined as the economic segment outside state-owned and state-holding enterprises. The domestic private sector is the broad private sector minus the foreign-invested enterprises and firms invested by people from Hong Kong, Macau and Taiwan. The narrow private sector is the domestic private sector minus collectively owned enterprises, meaning the privately owned and individual businesses only.

Source: Huang (2009).

SOEs. However, Chinese local governments still hold much power in determining who can enter into those 'deregulated' industries through various policy means. For example, the local governments still control land resources and bank loans. Without the support of local governments, privately owned enterprises can hardly enter into those lucrative industries. Even if they are allowed to enter into some industries, the privately owned enterprises may soon realize that they are competing with SOE giants on an unequal footing. For example, the oil industry is one of the most profitable industries in China; however, it is entirely monopolized by three state-owned oil companies, each of which controls a designated area and they normally do not compete directly with each other. Although private enterprises are allowed to enter into the petrol retailing segment, they only account for a minor share since the two oil giants, PetroChina and Sinopec, have adopted a strategy of aggressive acquisition of small and medium-size petrol stations.

A recent report clearly indicates the harsh operating environment of Chinese private enterprises. According to the 2010 Analytical Report on the Top 500 Private Enterprises published by the All-China Federation of Industry and Commerce, ${ }^{10}$ in 2009, the top 500 private enterprises dramatically improved their profitability. However, the profits of the 500 biggest private enterprises taken together totalled less than that of the two largest SOEs: China Mobile and PetroChina.

\section{The Impact on the SOEs}

The favourable conditions the SOEs enjoy create huge profits for them. But this is an illusion that conceals the truth of the lack of efficiency of the SOEs. This illusion and the huge profits in turn stimulate all sorts of opportunistic behaviour in SOEs that is detrimental to the SOEs and further reform. 
With the illusion of super-profitability, the managers of the SOEs are stimulated to undertake all sorts of opportunistic behaviour such as extravagant consumption on the job, giving extra welfare to SOE employees, conducting speculative investments in real estate and financial markets and engaging in corruption.

Consumption on the job includes expenditures on business-related travel, meals, telephone bills, training abroad, conferences, company cars, etc. Chen, Chen and Wan (2005), based on their analysis of the executive remuneration and consumption on the job of the listed SOEs from 1999 to 2002, found that on average SOE executives' annual consumption on the job was 12.3 times larger than their nominal remuneration. According to Chen, Liang, and Jiang (2010), from 1999 to 2008 , consumption on the job by the executives of China's A-share listed companies increased on average three times, while executive remuneration increased 4.8 times.

In 2005, according to the Unirule Institute of Economics (2011: 63), the average salary of SOE employees for the first time exceeded that of other enterprises, and since then the income gap has widened. In 2008 , the weighted average salary of an SOE employee was 17 per cent higher than that of an employee in a non-state-owned enterprise. For SOE employees, income not included in the salary is an important part of the total income; and in some monopolized industries, the percentage of income outside wages and salary is as high as 60 per cent of the total income. In China, wages and salaries of public sector employees are regulated by the government with a stipulated total amount for each working unit (danwei). However, this regulated total amount does not include expenditures on employee welfare, such as social insurance, housing allowance, extra insurance and transfer payments. Therefore, many SOEs take advantage of this regulation to give their managers and employees extra welfare-type incomes.

One big part of the extra welfare income is housing welfare. On 29 June 1998, the Chinese government abolished the welfare housing allocation policy, that is, it stopped giving public sector employees free houses as a part of employee welfare; instead employees were given cash allowances to buy houses in the housing market. Since 2003, house prices have increased rapidly with the boom of housing markets. While many ordinary Chinese people find it difficult to afford a flat to live in, many SOE employees still enjoy the housing welfare with high market value. This is because many SOEs can build their own welfare houses on the free land given by the Chinese government and then sell them to their employees 
at prices much lower than what the markets offer. Some SOEs also sign contracts with real estate developers to buy a large number of flats at lower-than-market prices and then resell them to their employees.

With huge profits on hand, many SOEs have started to speculate in real estate and financial markets as they see such investments as profitable. In 2009, 70 per cent of the 136 central SOEs were involved in real estate markets, although there are only 16 SOEs whose principal business is real estate (Unirule Institute of Economics 2011: 99). With the advantage of sufficient capital and access to cheap loans and credits, some SOEs behave like predators in real estate markets, often pushing land prices to record highs. In 2009, SOEs created several 'kings of land', pieces of land with the highest bid price in a city. Whether the SOEs who have bid on the 'kings of land' can make profits is not clear because of the relatively long cycle of the real estate business. In contrast, SOEs' speculation on the financial markets can make profits or losses quickly. According to the SASAC website, in 2009, 28 central SOEs were involved in financial derivatives trading, but made more losses than profits (Li 2010b).

With high profits and monopoly status, SOE managers are prone to corruption. For instance, in 2009, the CEO of Sinopec, Chen Tonghai, was arrested for embezzling 195.7 million yuan; ${ }^{11}$ in 2010, the vice chairman of China Mobile, Zhang Chunjiang, ${ }^{12}$ and the CEO of the Nuclear Industry Group, Kang Rixin, ${ }^{13}$ were arrested for receiving bribes of 7.5 million and 6.6 million yuan, respectively. However, the Ministry of Railway may be the most controversial case. Until March 2013, this ministry was the only one that had not separated its administrative and commercial functions. In fact, the ministry had long been an 'independent kingdom' within the Chinese government, as it combined many governmental functions such as military, police, law court, telecommunication and universities. It monopolized the construction and operation of railway networks. In recent years, the Chinese government has made massive investments to extend and upgrade the national rail network. In 2009, the Chinese government allocated a quarter of the 4 trillion yuan stimulus funds to railway construction. However, in 2010, several top officials of the ministry, including the minister, Liu Zhijun, and the deputy chief engineer, Zhang Shuguang, were arrested on corruption charges. The state media said that Liu pocketed more than 64.6 million yuan (US\$10.6 million) in kickbacks from companies that did business with his powerful office, ${ }^{14}$ while Zhang was said to have received 47.5 million yuan in bribes. ${ }^{15}$ At the annual meeting of the National People's Congress in 
March 2013, the Ministry of Railway was abolished. One part of it was merged with the Ministry of Transportation. Another more commercial part was turned into an SOE.

\section{The Impact on Society}

While a large part of the population has reached middle class status (or xiao kang in Chinese), social tensions and grievances have reached an alarmingly high level. Here, we focus on two issues, the high and rising investment rate and the widening income gaps in Chinese society. Chinese GDP growth has long been based on two engines, investment and export. Due to international pressure on China to reduce its trade surplus, the GDP-fixated Chinese government has now placed more emphasis on investment. The 'success' of SOEs has boosted the confidence of the Chinese government, which has reinforced belief in the correctness of the state-led investment-driven development strategy that the government has adopted. The high profits accruing to the SOEs also enable the continuation of this investment-based strategy. As a result, China's investment rate averaged 37.4 per cent for the period 1978-2008 (see Figure 1), rising from 36.5 per cent in 2001 to 48.6 per cent in $2010 .{ }^{16}$

The other side of the high investment rate is the low consumption rate. In Figure 2 we can see that the savings rate rose from 34.5 per cent in 1990 to 51.6 per cent in 2008. It seems there is a vicious circle in the Chinese economy: a high investment rate drives down the consumption

FIGURE 1: China's Investment and Consumption Rates (\%), 1978-2010

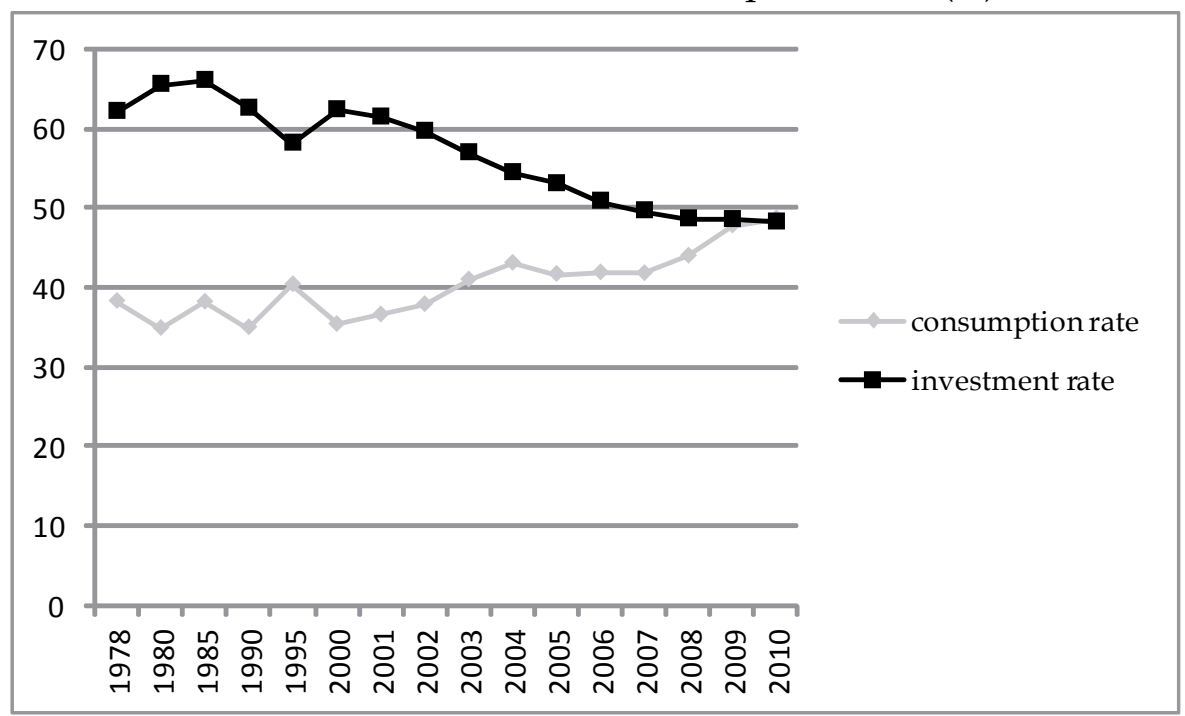

Source: China Statistical Yearbook (2011). 
rate and pushes up the savings rate, and the high savings rate enables a high investment rate. In the meantime, a high investment rate coupled with a low consumption rate produces excess capacity in many industries; excess capacity has to be channelled into export markets, which causes trade frictions.

Another problem caused by the high investment rate is rising inflation. In Table 7 we can see that China had rising inflation in 2004, 2007-2008 and 2010-2011. In 2012, the government managed to reduce inflation to

FIGURE 2: China's Savings Rate (\%), 1978-2008

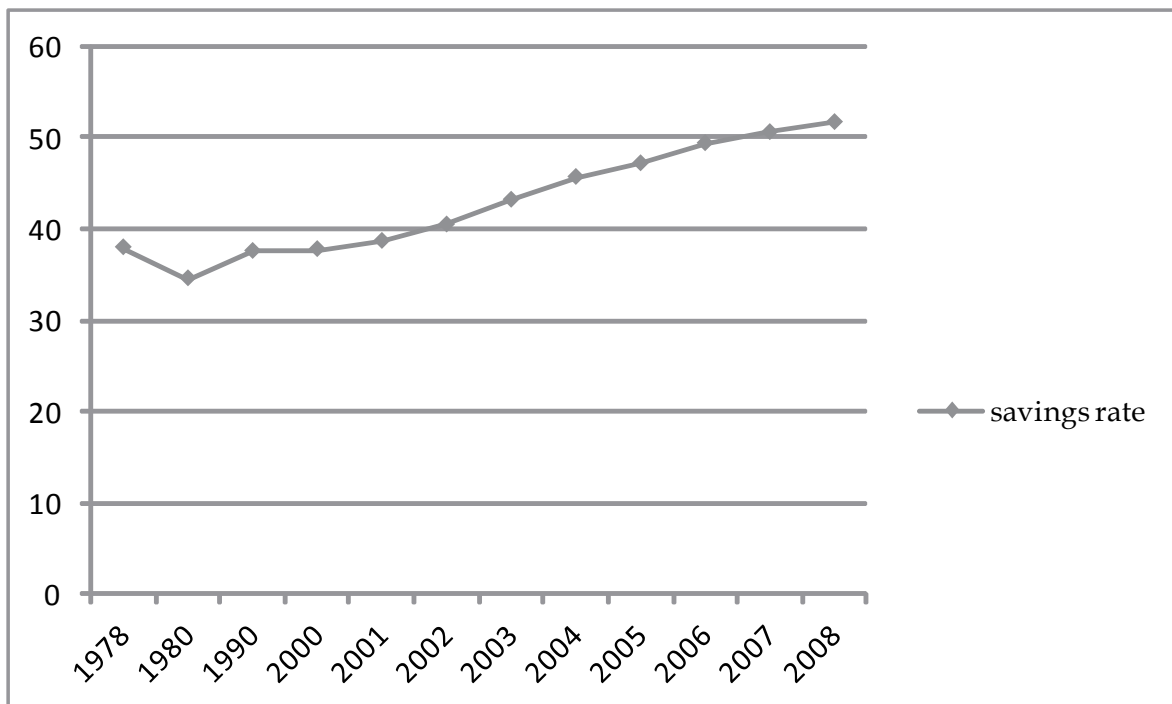

Source: China Statistical Yearbook (Various Years).

2.6 per cent. In recent years, a major component of the inflation has been rising food prices, which has caused difficulty for many poor Chinese. In 2011, the Chinese government made stabilizing price levels a priority of macroeconomic management. ${ }^{17}$

TABLE 7: China's Consumer Price Index, 2001-2012

\begin{tabular}{|l|c|c|c|c|c|c|c|c|c|c|c|c|}
\hline Year & 2001 & 2002 & 2003 & 2004 & 2005 & 2006 & 2007 & 2008 & 2009 & 2010 & 2011 & 2012 \\
\hline CPI & 0.7 & -0.8 & 1.2 & 3.9 & 1.8 & 1.5 & 4.8 & 5.9 & -0.7 & 3.3 & 5.4 & 2.6 \\
\hline
\end{tabular}

Sources: China Statistical Yearbook (2010); 2010-2012 figures are from China Xinhua News Agency: http://news.xinhuanet.com/fortune/2011-01/20/c_121003561.htm; http://news. xinhuanet.com/mrdx/2012-01/13/c_131358127.htm; and http://news.xinhuanet.com/ fortune/2013-01/12/c_124221229.htm.

From Figure 3, we can see that the labour share in China's GDP (i.e., the share of GDP that goes to labour) has been declining since the mid1990s. Another source claims that China's labour share peaked in 1983 
at 56.5 per cent and since then has declined for 22 consecutive years, decreasing a total of 20 per cent (Caijing 2010).

The decline of labour's share means the increase of capital's share in GDP, which is clearly reflected by rising corporate savings in China.

FIGURE 3: China's Labour Share in GDP (\%), 1996-2007

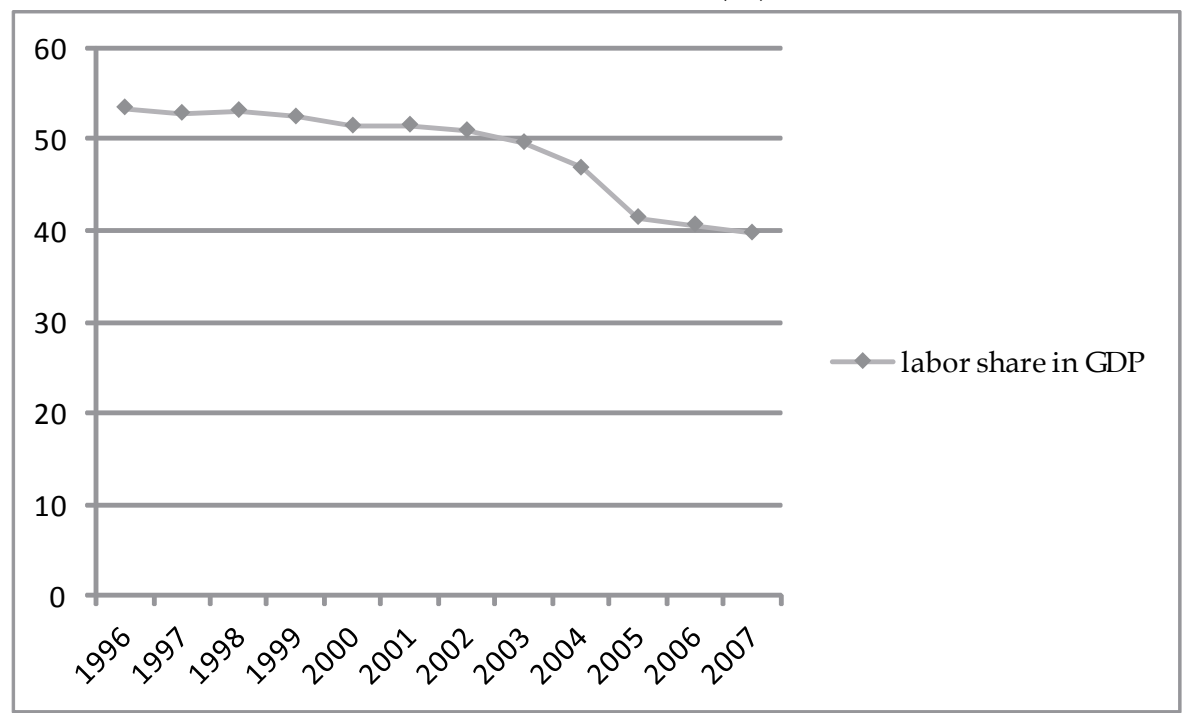

Source: China Statistical Yearbook (Various Years).

The decline of labour's share with the rise of capital's share in GDP has widened the income gap between wage earners and capital owners. In the meantime, due to the profit-seeking nature, a large chunk of investment capital has been channelled to the eastern coastal regions and manufacturing industries, which further contributes to the widening income gap between regions and between sectors. As a result, China's Gini coefficient has in general increased since the mid-1980s (see Figure 4) and has been close to 0.5 , above the warning level set by the UN.

Accompanying this widening income gap has been a rising number of 'mass disturbance' incidents in China (see Table 8). In 1993, there were 8,700 mass disturbances reported. This figure rose to 83,600 in 2005. Probably due to the negative impact of these figures, the Chinese government has stopped publishing the figure since 2006. However, high unofficial estimates have been reported. In today's China, the social psychology of hatred of rich people and government officials has emerged. A more serious problem caused by the widening income gap is the tendency for many people in a hopeless situation to take revenge against society, which is exactly the motive reported for several crimes targeting kindergarten children in 2010. 
FIGURE 4: China's Gini Coefficient, 1981-2012

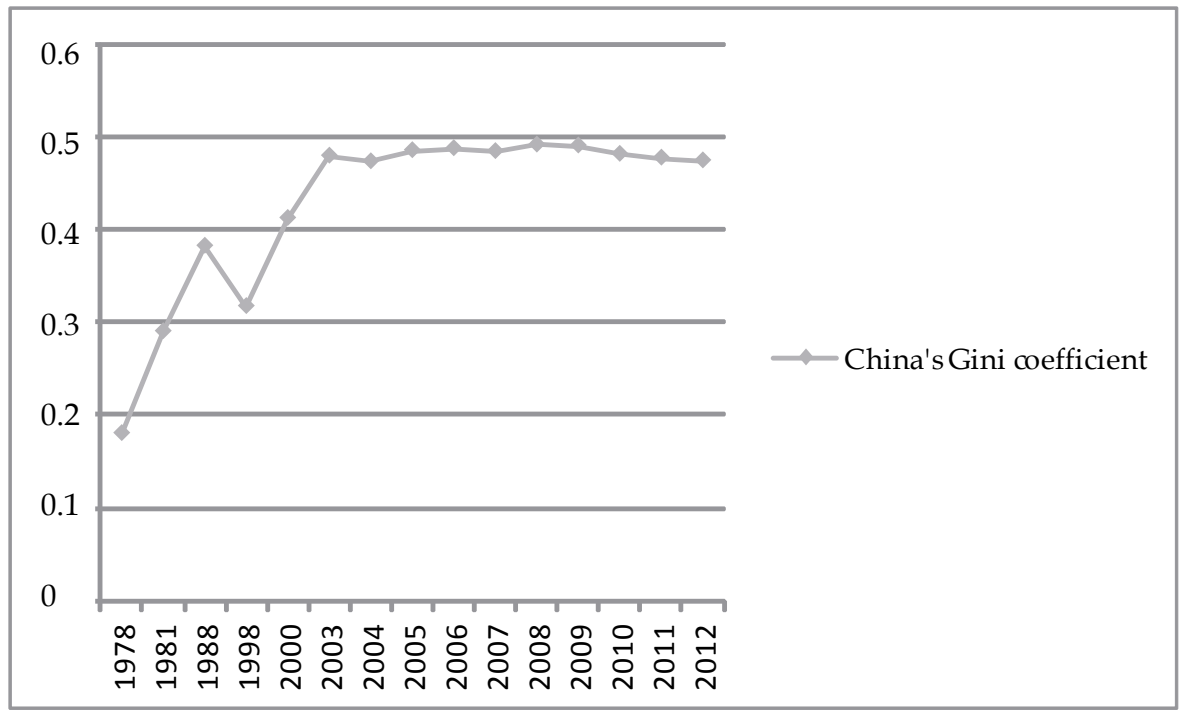

Source: China Statistical Yearbook (Various Years).

TABLE 8: Number of 'Mass Disturbances' in China

\begin{tabular}{|c|c|c|c|c|c|c|c|c|}
\hline Year & 1993 & 1994 & 1995 & 1996 & 1997 & 1998 & 1999 & 2000 \\
\hline Incidents & 8,700 & 10,000 & 11,000 & 12,000 & 15,000 & 25,000 & 32,000 & 40,000 \\
\hline Growth & & $15 \%$ & $10 \%$ & $9 \%$ & $25 \%$ & $67 \%$ & $28 \%$ & $25 \%$ \\
\hline lear & 2001 & 2002 & 2003 & 2004 & 2005 & 2006 & 2007 & 2008 \\
\hline Incidents & $\mathrm{n} / \mathrm{a}$ & 50,400 & 58,000 & 74,000 & 83,600 & $(90,000)$ & & $(120,000)$ \\
\hline Growth & & $12 \%$ & $15 \%$ & $28 \%$ & $13 \%$ & & & \\
\hline
\end{tabular}

Sources: Keidel (2006: 3, Table 1); 2006-2008 data are unconfirmed estimates (Tong and Lei 2010).

What will the Chinese government do to deal with the severe socialeconomic situation? It seems to be a dilemma for the government. On one hand, with increasing social tensions and grievances, the CCP feels the need to tighten its control of society, which explains why it has dramatically increased the national budget for 'maintaining social stability', which exceeded the national defence budget for the first time in 2011. On the other hand, after 30 years of opening up, Chinese society is much more pluralistic and Chinese intellectuals are much more liberal than before In addition, the wide use of the internet has made the Chinese public more informed and critical, and therefore the CCP is aware that it will be increasingly difficult to contain public grievances and to control public opinion without changing the policies that caused the very problem.

After three decades of reform guided by the slogan 'crossing the river by touching the stones', China is now at a critical juncture. A 
recent report by Tsinghua University scholars claims that the Chinese government has become so used to 'touching the stones' that it has lost the desire for 'crossing the river' (Institute of Social Progress 2012). The slow progress of reform is largely due to resistance from the vested interests that have grown during the gradualist reform period. Due to the complexity of the issue, Chinese leaders tend to avoid directly confronting the problems using the argument of maintaining social stability by solving the problem along the process of development. However, reality shows that the problems are not avoidable and tend to accumulate and become even more difficult to solve as the economy develops. One Chinese saying has it that it is less effective to block the flood than to channel it. We believe the Chinese government should now directly face the problems and take firm action to solve them.

\section{The Future: Where Will the New Leadership Take the SOE Reform?}

In November 2012, Xi Jinping succeeded Hu Jintao to become China's new top leader. It is unclear at present how Xi Jinping's personality and preferences will shape the direction of the Party's policy making. However, the country he is leading is very different from the one $\mathrm{Hu}$ Jintao took over from Jiang Zemin in 2003. In terms of the economy, while it is the world's second largest, it is widely believed to be unsustainable.

In November 2013, the CCP will hold its Third Plenum of the 18th Central Committee. It is unlikely that the new leaders will implement radical political reform in their first few years due to the political culture and possible resistance from vested interests; however, the new leaders will face many more demands from society than their predecessors. To really maintain social stability, perhaps the right thing for the new leaders to do is to further the economic reform. Specifically, with regard to SOE reform, the new leaders should follow the advice of the World Bank report, China 2030, to reduce the power and influence of the SOEs and leave more room for privately owned enterprises to flourish (World Bank 2012).

However, we don't see a quick privatization of SOEs as a feasible and desirable solution. Given the existence of vested interests and current political reality, a rapid privatization of SOEs would result in a situation similar to what happened in Russia in the early 1990s during its phase of so-called shock therapy, i.e., some powerful people will be able to 
grab or convert vast state-owned assets into private property. This is highly likely given the reality that this is exactly what happened in the past privatization process.

Among other things, future SOE reform needs, first, to deregulate the industries in which SOEs monopolize or dominate, i.e., to introduce competition to SOEs by allowing private firms to enter into these industries; second, to replace CCP-appointed SOE managers with professional managers by publicly recruiting talent globally and making the new managers accountable not to the Party but to their boards of directors and shareholders; and third, to empower the newly recruited professional managers to revolutionize corporate management in order to gradually get rid of the SOE culture that is characterized by bureaucracy, inefficiency and complacency.

Given the resistance from vested interests, it seems that such further economic reform necessitates at least a modest political reform. However, whether the new leaders want and are able to implement such political reform is an open question.

Xin Li is Assistant Professor of International Business at Asia Research Centre, Department of International Business and Management, Copenhagen Business School. His research interests include China studies, international business, and strategic management.

Kjeld Erik Brødsgaard is Professor at the Department of International Economics and Management and Director of Asia Research Centre, Copenhagen Business School. His research interests include state, Party and public management in China; the nomenklatura system and cadre management; and the structure and impact of Chinese business groups in China as well as on the global-level playing field.

\section{NOTES}

1 The concept of planned commodity economy was put forward at the Third Plenary Session of the 12th Central Committee of the Chinese Communist Party on 20 October 1984. See People's Daily Online, available from: http:/ / english.people. com.cn/90002/95589/6512383.html.

2 See the text of the Law at http://news.xinhuanet.com/ziliao/2005-03/02/content_2637322.htm.

3 This information can be found on the official website of the SASAC. Available from: http:/ / www.sasac.gov.cn/n2963340/n2963393/2965120.html.

4 China's state-owned financial assets are supervised by the Ministry of Finance.

5 China Xinhua News Agency, available from: http://news.xinhuanet.com/poli- 
tics/2009-12/12/content_12634931.htm.

6 Between 1994 and 2006, Chinese SOEs paid taxes but no dividends to the state. From 2007, Chinese SOEs were requested to pay dividends. Most SASAC firms would only remit 5 per cent of their after-tax profits and the maximum 10 per cent would apply to only 17 companies (Brødsgaard 2012). From 2011, the Chinese government raised by 5 percentage points the rate of dividends the SOEs have to pay to the state.

7 China Xinhua News Agency, available from : http://news.xinhuanet.com/politics/2009-12/12/content_12634931.htm

8 The report is available at: http://www.china.com.cn/news/zhuanti/ 09myjjlps/2009-09/28/content_18621412.htm.

9 See People's Bank of China base interest rate, avaiable from: http://www. pbc.gov.cn/publish/zhengcehuobisi/631/2012/20120706181352694274852 /201200706181352694274852_html

10 China Xinhua News Agency, available from: http:/ / news.xinhuanet.com/fortune/2010-08/30/c_12497719.htm.

11 China Xinhua News Agency, available from: http://news.xinhuanet.com/politics/2009-07/15/content_11711240.htm.

12 China Xinhua News Agency, available from: http:/ / news.xinhuanet.com/legal/2011-07/22/c_121708021.htm.

13 China Xinhua News Agency, available from: http://news.xinhuanet.com/legal/2010-11/20/c_12796129.htm.

14 China Xinhua News Agency, available from: http://news.xinhuanet.com/legal/2013-07/08/c_116442565.htm.

15 China Xinhua News Agency, available from: http://news.xinhuanet.com/fortune/2013-09/10/c_117297357.htm.

16 People's Daily (2011), 'Women neng fou kuaguo zhongdeng shouru xianjing'(Can we cross the middle-income trap)' July 25. Available from: http://news.xinhuanet.com/politics/2011-07/25/c_121715266.htm.

17 China Xinhua News Agency, available from: http:// news.xinhuanet.com/politics/2011-08/25/c_121912021.htm.

\section{REFERENCES}

All China Federation of Industry and Commerce 2009. Development Report of China's Private Economy. Beijing: Social Sciences Academic Press.

All China Federation of Industry and Commerce 2010. Analytical Report on the Top 500 Private Enterprises. Available from: http://www.acfic.org.cn/zt/10/sgm500/ fenxibaogao.pdf.

Bayoumi,T., H. Tong, and S.-J. Wei 2010. 'The Chinese corporate savings puzzle: A firm-level cross-country perspective'. IMF Working Paper WP/10/275. Washington, DC: International Monetary Fund.

Brødsgaard, K. E. 2012. 'Politics and Business Group Formation in China: The Party in Control?' The China Quarterly 211 (September): 644-648.

Caijing 2010. 'China's Labor Share of GDP Declined for 22 Consecutive Years', May 12. Available from: http://english.caijing.com.cn/2010-05-12/110437827.html.

Caijing 2012. 'Guoziwei wei he dui shihang tuijin Zhongguo guo qi gaige de baogao qianglie fandui' (Why SASAC Strongly Opposed the World Bank Report on Furthering Chinese SOE Reform), March 1. Available from: http://comments.caijing. com.cn/2012-03-01/111720673.html. 
Central Committee of the Communist Party of China 1999. 'Zhonggong zhongyang guanyu guoyuo qiye gaige he fazhan ruogan zhongda wenti de jueding' (The CCP Central Committee's decision on SOE reform and development and some other important issues), September 22, 1999. Available from: http://cpc.people. com.cn/GB/64162/71380/71382/71386/4837883.html.

Chang, H. J. 2007. State-owned enterprise reform. Department for Economic and Social Affairs (UNDESA) Policy note.

Chen, D. H., X. Y. Chen, and H. L. Wan 2005. 'Guoyou qiye zhong de xinchou guanzhi yu zaizhi xiaofei' (Remuneration control and consumption on the job in SOEs). Jingji Yanjiu (Economic Research) 2: 92-101 (in Chinese).

Chen, D. H., S. K. Liang, and D. Q. Jiang 2010. 'Butong shichanghua jincheng xia gaoguan jili qiyue de chengben yu xuanzhe: Huobi xinchou yu zaizhi xiaofei' (The costs and choices of executive incentive contracts under different degree of marketization: monetary remuneration and consumption on the job). Kuaiji Yanjiu (Accounting Research) 11: 56-64 (in Chinese).

Chen, Q. 2012. 'SOE Reform Once Again in the Spotlight'. Caijing, May 22. Available from: http:/ / english.caijing.com.cn/2012-05-22/111855690.html.

China Statistical Yearbook, various years. Beijing: China National Bureau of Statistics of China.

Huang Mengfu 2009. Zhongguo minying jingji fazhan baogao (Annual Report of NonState-Owned Economy in China) 6 (2008-2009). Beijing: Shehui Kexue Wenxian Chubanshe (Social Sciences Academic Press).

Institute of Social Progress, Kaifeng Research Academy, Tsinghua University 2012. "'Zhongdeng shouru xianjing"' haishi "'zhuanxing xianjing? "' ("Middle income trap" or "Transitional trap"?) Available from: http:/ / www.citygf.com/cul/ nfjt/11/09/201205/W020120521624380174222.pdf.

Keidel, A. 2006. 'China's social unrest: The story behind the stories'. Policy Brief 48 (September), Carnegie Endowment for International Peace.

Lardy, N. 2008. 'Financial Repression in China'. Policy Brief No. PB08-8, Peterson Institute of International Economics, September. Available at: http://www.iie. $\mathrm{com} /$ publications/interstitial.cfm?ResearchID=999.

Li, J. Z. 2008. 'Irregular Credit Completely Offsets the Retrenchment Gap'. China Economic Management Report, July 6.

Li Rongrong 2003. '196 jia zhongyang qiye shixing guquan duoyanghua bu hui siyouhua' (196 SOEs Will Diversify Their Shares But Not Privatize), July 9. Available from: http:/ /xxgk.sasac.gov.cn/gips/contentSearch?id=7382712.

Li Rongrong 2009. 'Zou Zhongguo tese guoyou qiye gaige fazhan zhi lu' (Following the Development Road of SOE Reform With Chinese Characteristics) (interview), June 2. (Originally published in Xuexi shibao (Study Times)). Available from: http://theory.people.com.cn/GB/49154/49155/9396825.html.

Li Rongrong 2010a. 'Xierenshi de jianghua' (The Retirement Speech of Li Rongrong), August 24. Available from: http:/ / news.xinhuanet.com/fortune/2010-09/03/ c_12516557.htm.

Li Rongrong 2010b. 'Yangqi Buyao "Dongzhang Xiwang"' (Central SOEs should not 'look east and look west'), People's Daily, May 6. Available from: http://theory. people.com.cn/GB/11528593.html.

Lin, Y. F., and Z. Y. Li 2003. 'Zhongguo de guoyou qiye yu jinrong tizhi gaige' (China's state-owned enterprise and financial system reforms). Working Paper No.

C2003027, China Centre for Economic Research, Peking University (in Chinese).

Nolan, P. 2002. 'China and the global business revolution'. Cambridge Journal of Eco- 
Xin Li and Kjeld Erik Brødsgaard

nomics 26 (1): 119-137.

SASAC (State-owned Assets Supervision and Administration Commission of the State Council of the People's Republic of China) 2008. 'Sannian tuokun' (Getting out of Difficulties within Three Years), September 25. Available from: http:/ / www.sasac.gov.cn/n1180/n4175042/n5405123/n5564463/5564529.html.

SASAC 2010. 'SASAC Review 2009'. Available from: http:/ /www.sasac.gov.cn/ n1180/n13307665/n13307681/n13307749/13333552.html.

Szamosszegi, A., and C. Kyle 2011. An Analysis of State-owned Enterprises and State Capitalism in China. Washington, DC: US-China Economic and Security Review Commission.

Tong, Y., and S. Lei 2010. 'Large-scale mass incidents in China'. East Asia Policy 2 (2): 22-33.

Unirule Institute of Economics 2011. The Nature, Performance, and Reform of the Stateowned Enterprises 16 June 2011 version.

World Bank 2012. China 2030. Washington, DC: The World Bank.

Xi Jinping 2009. 'Xi Jinping qiangdiao yi gaige chuangxin jingshen tuijin guoyou qiye dang de jianshe (Xi Jinping emphasizes further Party-building in SOEs with the spirit of reform and innovation). China Xinhua News Agency, August 17. Available from: http://news.xinhuanet.com/ politics/2009-08/17/content_ 11899204.htm. 